\title{
Erratum to: Taxation of a Polluting Non-renewable Resource in the Heterogeneous World
}

\author{
Julien Daubanes · André Grimaud
}

(C) Springer Science+Business Media B.V. 2011

\section{Erratum to: Environ Resource Econ (2010) 47:567-588 DOI 10.1007/s10640-010-9393-2}

Due to an omission, the link to the electronic supplementary material (ESM), was not included in the original article. Please see below for this link.

Electronic supplementary material The online version of this article (doi:10.1007/s10640-011-9459-9) contains supplementary material, which is available to authorized users.

The online version of the original article can be found under doi:10.1007/s10640-010-9393-2.

J. Daubanes $(\square)$

CER-ETH at ETHZ, Swiss Federal Institute of Technology Zürich, ZUE F12, Zürichbergstrasse 18, 8092 Zürich, Switzerland

e-mail: jdaubanes@ethz.ch

A. Grimaud

IDEI and LERNA at TSE, Toulouse School of Economics, and ESCT, Toulouse Business School, Toulouse, France 